\title{
Dietary effects of faba-bean (Vicia faba L.) tannins on the morphology and function of the small-intestinal mucosa of
} weaned pigs

\author{
BY P. VAN LEEUWEN, A. J. M. JANSMAN AND J. WIEBENGA \\ TNO Nutrition and Food Research, Department of Animal Nutrition and Physiology (ILOB), \\ PO Box 15, 6700 AA Wageningen, The Netherlands \\ AND J. F. J. G. KONINKX AND J. M. V. M. MOUWEN \\ Department of Veterinary Pathology, Faculty of Veterinary Medicine, University of Utrecht, \\ Yalelaan 1, PO Box 80.158, 3508 TD Utrecht, The Netherlands
}

(Received 21 March 1994-Accepted 7 June 1994)

\begin{abstract}
The objective of the present study was to evaluate effects of condensed tannins in faba beans ( $V i c i a$ faba L.) on morphological and functional variables of the small-intestinal mucosa of piglets. In an experiment with young piglets ( $8-17 \mathrm{~kg}$ body weight), fed on either a control diet or a diet containing $200 \mathrm{~g} / \mathrm{kg}$ of low- or high-tannin faba bean hulls (with $<0.10$ and $3.3 \%$ catechin equivalents of condensed tannins respectively), morphological and functional characteristics of the jejunal mucosa were determined. Results of the study showed that the morphological variables of the mucosa of the three groups of piglets were similar. Also, no changes due to dietary tannins were observed in sucrase (EC 3.2.1.48)-isomaltase $(E C 3.2 .1 .10)$ activity in homogenates of mucosa plus submucosa. However, aminopeptidase (EC 3.4.11.2) activity in these homogenates in the proximal part of the small intestine of the animals of the group fed on the high-tannin diet was significantly lower than that in the animals fed on the control diet or the diet with low-tannin hulls $(P<0.05)$.
\end{abstract}

Tannins: Enzyme activities: Pig

Faba beans (Vicia faba L.) are an important protein source in rations for livestock. However, their nutritive value is limited by the presence of condensed tannins (Marquardt et al. 1977; Martin-Tanguy et al. 1977; Jansman, 1993). Condensed tannins are watersoluble polyphenolic compounds with the ability to precipitate proteins from aqueous solutions (Bate-Smith \& Swain, 1962) and are found particularly in the hull fraction of coloured-flowering faba bean varieties (Bos \& Jetten, 1989). Tannins have been shown to reduce apparent protein digestibility in diets for non-ruminant animal species (Salunkhe et al. 1990). The white-flowering varieties have a much lower tannin content than the coloured varieties and are generally more digestible. An explanation for the antinutritional effect of tannins is that these compounds have an affinity for proteins which results in poorly digestible tannin-protein complexes. Experiments with rats proved that the protein of these complexes originates partly from feed and partly from salivary protein (Jansman, 1993). Also, an increased endogenous $\mathrm{N}$ excretion was observed in piglets after feeding tannincontaining diets (Jansman et al. 1993). This finding indicates an enhanced turnover of mucus and/or glycocalyx. The mucus layer and the glycocalyx are important factors in the protection of epithelial integrity of the small intestine (Mouwen et al. 1983; Egberts et al. 1984). In addition, the glycocalyx contains various digestive enzymes (Egberts et al. 1984). 
Binding of tannins to mucins or the glycocalyx may change their biochemical and physical properties. Effects of tannins on morphological variables of the intestinal mucosa have been observed in rats (Mitjavila et al. 1977). Moreover, this binding could affect the functional capacity of the mucosa, such as the activity of brush-border enzymes.

The nutritional implications of tannin-rich hulls of faba beans have been studied in a digestibility experiment with piglets (Jansman et al. 1993). The present study evaluated the effects of condensed tannins in hulls of faba beans on the mucosal structure and the activities of digestive enzymes of the small intestinal mucosa using tissue from the piglets used in the digestibility experiment.

\section{MATERIALS AND METHODS}

\section{Animals and rations}

Three groups of eight, seven and eight conventional piglets, with a mean body weight of $12 \mathrm{~kg}$, were fed on either a control ration $(1$; treatment group 1$)$ or any of the two rations containing $200 \mathrm{~g} / \mathrm{kg}$ of hulls of a white- (ration 2; treatment group 2) and a colouredflowering variety (ration 3; treatment group 3) of faba beans (Vicia faba L.). Each diet contained barley and maize as major ingredients. In ration 1 autoclaved hulls from peas (Pisum sativum) were added to ensure that the fibre contents of the rations were the same. After a period of adaptation the animals were fed on the rations over an experimental period of $23 \mathrm{~d}$. Throughout the experiment the animals were fed twice daily, at 08.00 and 17.00 hours. Water was freely available via drinking nipples. Details of the preparation of the hulls, feed formulation and the zootechnical protocol have been described elsewhere (Jansman et al. 1993).

On day 24, three samples of small intestine from each animal were taken under general anaesthesia. Sites were: sample a, $0.5 \mathrm{~m}$ distal to the ligament of Treitz; sample b, $5.5 \mathrm{~m}$ distal to the ligament of Treitz; sample c, $0.5 \mathrm{~m}$ proximal to the ileo-caecal ligament. The samples were evaluated using morphological and functional variables.

The experiment was approved by the TNO Committee for Animal Welfare.

\section{Assays on morphological characteristics}

Dissecting microscopy. Each sample of small intestine was cut open longitudinally at the antimesenteric attachment, affixed on dental wax with the villi on the upper side and fixed in $0 \cdot 1 \mathrm{M}$-phosphate-buffered formalin solution $(40 \mathrm{ml} / \mathrm{l})$. The shape of the villi was studied with a dissecting microscope and characterized according to a previously described procedure (Mouwen, 1972) using the following grading system: grade 0, a normal villus pattern with almost all finger-shaped villi; grade 0.5 , mixed finger- and tongue-shaped villi; grade 1, predominantly long to short tongue-shaped villi with few finger-shaped and leafshaped ones; grade 1.5 , predominantly short tongue- and leaf-shaped villi with few long tongue- and ridge-shaped villi; grade 2 , mixture of short tongue-, leaf- and ridge-shaped and convoluted villi; grade $2 \cdot 5$, similar to grade 2 , but with flat areas; grade 3 , flat mucosa. For this evaluation the mesenteric part of the mucosa, outside the Peyer's patches, was taken into consideration.

Morphometry and histochemistry. After the dissecting microscopical study a $3 \mathrm{~mm}$ wide zone from the mesenteric site was cut at right angles to the surface of the mucosa and embedded in paraffin wax. As the Peyer's patches are on the antimesenteric site of the intestine, the regions with Peyer's patches were not included in the microscopic slides studied. Sections were cut $(5 \mu \mathrm{m})$ and stained with haematoxylin and eosin (HE staining) and the periodic acid-Schiff method (PAS staining). From these stained sections villus 
height, crypt depth, villus : crypt ratio, index of mitosis (meta- and anaphases) per $100 \mathrm{crypt}$ cells, goblet cells (number per $100 \mu \mathrm{m}$ crypt and number per crypt) were determined according to previously described procedures (Kik et al. 1990).

Transmission electron microscopy $(T E M)$. From each sample a piece of luminal tissue was taken from the site of the mesenteric attachment for TEM to determine the length of the microvilli. Tissue processing consisted first of fixation in $0.1 \mathrm{M}$-cacodylate-buffered

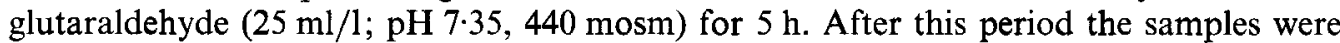
rinsed with $0.1 \mathrm{M}$-cacodylate buffer ( $\mathrm{pH} 7.35$ ) and stored in $0.1 \mathrm{M}$-cacodylate buffer $\left(\mathrm{pH} 7.35\right.$ ) with $70 \mathrm{~g}$ sucrose $/ 1$ at $4^{\circ}$ until final processing. Final processing consisted of postfixation with osmium tetroxide in $0.1 \mathrm{M}$-cacodylate buffer $(20 \mathrm{~g} / 1 ; \mathrm{pH} 7 \cdot 35)$ for $16 \mathrm{~h}$ at $4^{\circ}$ followed by dehydration in graded water-acetone mixtures and embedding in an Epon-Araldite mixture. From the embedded samples, ultrathin $(600-800 \AA)$ sections were cut and stained with uranylmagnesium acetate and lead citrate. The stained sections were examined with a Philips CM 10 electron microscope at $80 \mathrm{kV}$.

\section{Enzyme activity in homogenates of mucosa and submucosa}

The functional variables investigated were sucrase (EC 3.2.1.48)-isomaltase $(E C 3.2 .1 .10)$ and aminopeptidase (EC 3.4.11.2) activity of homogenates of smallintestinal mucosa plus submucosa. Samples of the intestinal tissue for these determinations were frozen in liquid $\mathrm{N}_{2}$ and stored at $-70^{\circ}$ until required for analysis. Homogenates of mucosa plus submucosa were made and analysed for sucrase-isomaltase and aminopeptidase activity. The enzyme activities were expressed in units (U) per g protein in the homogenates. Protein contents of the homogenates were determined as described (Lowry et al. 1951).

Sucrase-isomaltase enzyme activity. The principle of determination of sucrase-isomaltase activity is based on the degradation of sucrose (substrate) to glucose and fructose by sucrase-isomaltase in the homogenate. Reaction time was $60 \mathrm{~min}$ at $37^{\circ}$. Glucose is determined after glucose oxidase $(E C$ 1.1.3.4)-peroxidase $(E C 1.11 .1 .7)$ treatment, staining and measuring the intensity of the colour at $405 \mathrm{~nm}$ spectrophotometrically. The analysis was carried out as a micromethod on microtitre plates. On the same plate standard dilutions of glucose and dilutions of the samples were made and measured after incubation with a microplate reader (BioRad model 3550; BioRad, Veenendaal, The Netherlands).

Sucrase-isomaltase activity is expressed in units (U) per g protein. One unit is equal to the production of $1 \mu \mathrm{mol}$ glucose/min from the sucrose substrate. The determination of sucrase-isomaltase activity has been described previously (Messer \& Dahlqvist, 1966).

Aminopeptidase enzyme activity. The determination of the aminopeptidase activity is based on the hydrolysis of L-alanine-p-nitroanilide (substrate) to $p$-nitroaniline and Lalanine by the aminopeptidase in the homogenate. Reaction time was $20 \mathrm{~min}$ at $37^{\circ}$. The $p$-nitroaniline is determined by staining and measuring the intensity of the colour at $405 \mathrm{~nm}$ spectrophotometrically. The analyses were carried out as a micromethod on microtitre plates. On the same plate standard dilutions of $p$-nitroaniline and dilutions of the samples were made and measured after incubation with a microplate reader (Biorad model 3550; BioRad).

Aminopeptidase activity is expressed in units (U) per g protein. One unit is equal to the production of $1 \mu \mathrm{mol} p$-nitroaniline/min from the L-alanine-p-nitroanilide substrate. The method for the determination of aminopeptidase activity has been described previously (Maroux et al. 1973). 
Table 1. Morphological characteristics of the villi and crypts in different parts of the smallintestinal mucosa from pigs of the control (treatment group 1) and experimental groups (lowand high-tannin rations; treatment groups 2 and 3 respectively) for samples $a$ and $b, 0.5$ and $5.5 \mathrm{~m}$ distal from the ligament of Treitz respectively and $c, 0.5 \mathrm{~m}$ proximal to the ileo-caecal ligament*

\begin{tabular}{|c|c|c|c|c|}
\hline $\begin{array}{l}\text { Treatment group... } \\
n \ldots\end{array}$ & $\begin{array}{l}1 \\
8\end{array}$ & $\begin{array}{l}2 \\
7\end{array}$ & $\begin{array}{l}3 \\
8\end{array}$ & SEM \\
\hline \multicolumn{5}{|c|}{ Dissecting microscopical gradation ( $0-3)$} \\
\hline \multicolumn{5}{|c|}{ Sample } \\
\hline a & $1 \cdot 3$ & $1 \cdot 1$ & $1 \cdot 3$ & $0 \cdot 1$ \\
\hline $\mathbf{b}$ & $1 \cdot 2$ & $1 \cdot 3$ & $1 \cdot 2$ & 0.2 \\
\hline c & $1 \cdot 1$ & 0.7 & $0 \cdot 7$ & $0-2$ \\
\hline Mean & $1 \cdot 2$ & $1 \cdot 0$ & $1 \cdot 1$ & 0.1 \\
\hline \multicolumn{5}{|l|}{ Villus height $(\mu \mathrm{m})$} \\
\hline a & 590 & 600 & 642 & 55 \\
\hline $\mathbf{b}$ & 540 & 559 & 599 & 38 \\
\hline $\mathrm{c}$ & 415 & 448 & 454 & 40 \\
\hline Mean & 515 & 536 & 565 & 27 \\
\hline \multicolumn{5}{|l|}{ Crypt depth $(\mu \mathrm{m})$} \\
\hline$a$ & 313 & 350 & 339 & 25 \\
\hline b & 309 & 304 & 318 & 20 \\
\hline $\mathrm{c}$ & 251 & 243 & 222 & 10 \\
\hline Mean & 291 & 299 & 293 & 14 \\
\hline \multicolumn{5}{|l|}{ Villus: crypt ratio $(\mu \mathrm{m} / \mu \mathrm{m})$} \\
\hline a & 1.9 & 1.8 & 2.0 & 0.2 \\
\hline $\mathrm{b}$ & 1.8 & 1.9 & 1.9 & $0 \cdot 1$ \\
\hline c & 1.7 & 1.9 & $2 \cdot 1$ & 0.2 \\
\hline Mean & 1.8 & 1.8 & $2 \cdot 0$ & 0.1 \\
\hline
\end{tabular}

* For details of rations and procedures, see pp. 32-33.

Statistical analysis

One-way analysis of variance was carried out using software package SPSS/PC + V5.0 (SPSS, 1992) on the experimental data using treatment as a factor. If the treatment effect was significant the differences between means were tested using the least significance difference (LSD) test (Snedecor \& Cochran, 1980). The correlation between protein digestibility and aminopeptidase activity was analysed by using software package SPSS/PC + V5.0 (SPSS, 1992).

\section{RESULTS}

Morphological characteristics of the small intestinal mucosa

Villus height and crypt depth. No significant differences $(P<0 \cdot 05)$ in the villus height and crypt depth between the three groups of animals were observed (Table 1). The results show rather large differences in morphological variables between animals (SEM 5-10\% of the absolute values). There was a general tendency for villus height and crypt depth to decrease from the proximal to the distal part of the small intestine.

Index of mitosis and number of goblet cells. The results with respect to these variables were 
Table 2. Index of mitosis and number of goblet cells in different parts of the small intestinal mucosa from pigs of the control (treatment group 1) and experimental groups (low-and hightannin rations; treatment groups 2 and 3 respectively) for samples $a$ and $b, 0.5$ and $5.5 \mathrm{~m}$ distal from the ligament of Treitz respectively and sample c, $0.5 \mathrm{~m}$ proximal to the ileo-caecal ligament*

\begin{tabular}{|c|c|c|c|c|}
\hline $\begin{array}{l}\text { Treatment group... } \\
n \ldots\end{array}$ & $\begin{array}{l}1 \\
8\end{array}$ & $\begin{array}{l}2 \\
7\end{array}$ & $\begin{array}{l}3 \\
8\end{array}$ & SEM \\
\hline \multicolumn{5}{|c|}{ Index of mitosis (no. per 100 crypt cells) } \\
\hline $\begin{array}{l}\text { Sample } \\
\text { a }\end{array}$ & 1.8 & 1.9 & 1.6 & 0.3 \\
\hline b & $2 \cdot 7$ & 3.0 & $2 \cdot 9$ & 0.4 \\
\hline c & $4 \cdot 3$ & $3 \cdot 1$ & $4 \cdot 1$ & 0.5 \\
\hline Mean & $2 \cdot 9$ & $2 \cdot 7$ & $2 \cdot 9$ & 0.2 \\
\hline \multicolumn{5}{|c|}{ Goblet cells (no. per crypt) } \\
\hline $\mathrm{a}$ & $23 \cdot 7$ & $24 \cdot 6$ & $23 \cdot 2$ & $3 \cdot 2$ \\
\hline $\mathrm{b}$ & $20 \cdot 8$ & $20 \cdot 2$ & $21 \cdot 3$ & 1.9 \\
\hline $\mathbf{c}$ & $24 \cdot 4$ & $25 \cdot 4$ & $22 \cdot 1$ & 1.5 \\
\hline Mean & $22 \cdot 9$ & $23 \cdot 4$ & $22-2$ & 1.6 \\
\hline \multicolumn{5}{|c|}{ Goblet cells (no. per $100 \mu \mathrm{m}$ crypt) } \\
\hline a & $7 \cdot 4$ & 6.9 & 6.8 & 0.6 \\
\hline b & $6 \cdot 8$ & 6.8 & $6 \cdot 6$ & 0.5 \\
\hline $\mathrm{c}$ & $9 \cdot 7$ & $10 \cdot 5$ & $9 \cdot 9$ & 0.5 \\
\hline Mean & $8 \cdot 0$ & $8 \cdot 1$ & $7 \cdot 8$ & 0.4 \\
\hline
\end{tabular}

* For details of rations and procedures, see pp. 32-33.

Table 3. Length of microvilli in different parts of the small-intestinal mucosa from pigs of the control (treatment group l) and experimental groups (low-and high-tannin rations; treatment groups 2 and 3) for samples $a$ and $b, 0.5$ and 5.5 distal from the ligament of Treitz respectively and sample $c, 0.5$ m proximal to the ileo-caecal ligament*

\begin{tabular}{lllll}
\hline \hline Treatment group ... & 1 & 2 & 3 & \\
$n \ldots$ & 8 & 7 & 8 & SEM \\
\hline Length of microvilli $(\mu \mathrm{m})$ & & & & \\
$\quad$ Sample & & & & \\
a & 1.5 & 1.6 & 1.6 & 0.1 \\
b & 1.9 & 2.0 & 1.8 & 0.2 \\
c & 1.9 & 2.1 & 1.6 & 0.2 \\
Mean & 1.8 & 1.9 & 1.7 & 0.1 \\
\hline \hline
\end{tabular}

* For details of rations and procedures, see pp. 32-33.

similar for the different groups and no significant changes due to the presence of tannins in the ration were observed (Table 2). The index of mitosis tended to be higher in the distal part of the small intestine.

Length of the microvilli. No significant differences in length of the microvilli between the three groups were observed (Table 3 ). There was a tendency for the microvilli in samples b and $c$ of treatment group 2 to be longer than those of treatment groups 1 and 3 . This difference was not related to the tannin content of the rations. 
Table 4. Functional characteristics of the small-intestinal samples from pigs of the control (treatment group 1) and experimental groups (low-and high-tannin rations; treatment groups 1 and 2 respectively) for samples $a$ and $b, 0.5$ and $5.5 \mathrm{~m}$ distal from the ligament of Trietz respectively and sample $c, 0.5 \mathrm{~m}$ proximal to the ileo-caecal ligament*

\begin{tabular}{|c|c|c|c|c|c|}
\hline & $\begin{array}{l}\text { Treatment group } \ldots \\
n \ldots\end{array}$ & $\begin{array}{l}1 \\
8\end{array}$ & 2 & $\begin{array}{l}3 \\
8\end{array}$ & SEM \\
\hline & \multicolumn{5}{|c|}{$\begin{array}{l}\text { Sucrase (EC 3.2.1.48)-isomaltase (EC 3.2.1.11) } \\
\text { activity (units } \dagger / \text { g protein) } \\
\text { Sample }\end{array}$} \\
\hline & a & 45 & 49 & 40 & 10 \\
\hline & b & 61 & 78 & 86 & 14 \\
\hline & $\mathrm{c}$ & 61 & 66 & 64 & 13 \\
\hline \multicolumn{6}{|c|}{ Mean } \\
\hline & $a$ and $b$ & 53 & 64 & 63 & 9 \\
\hline & $a-c$ & 56 & 64 & 63 & 8 \\
\hline \multicolumn{6}{|c|}{$\begin{array}{l}\text { Aminopeptidase ( } E C 3.4 .11 .2) \text { activity (units } \ddagger / g \text { protein) } \\
\text { Sample }\end{array}$} \\
\hline & a & $118^{a}$ & $111^{a . b}$ & $66^{b}$ & 16 \\
\hline & $\mathrm{b}$ & $109^{a}$ & $108^{\mathrm{a}}$ & $65^{a}$ & 19 \\
\hline \multicolumn{6}{|c|}{$\stackrel{c}{c}$} \\
\hline & $a$ and $b$ & $113^{\mathrm{a}}$ & $110^{\mathrm{a}}$ & $65^{b}$ & 13 \\
\hline & $a-c$ & $112^{\mathrm{a}}$ & $120^{a}$ & $92^{\mathrm{a}}$ & 15 \\
\hline
\end{tabular}

\section{Enzyme activity in homogenates of mucosa and submucosa}

Sucrase-isomaltase activity. The data of the biochemical analyses showed large standard errors of means (Table 4). The sucrase-isomaltase activities in sample b of the animals fed on the rations with the faba-bean hulls (groups 2 and 3) tended to be higher than that of the control group (1). This tendency was also found in sample $c$. However, these differences were not significant.

Aminopeptidase activity. Aminopeptidase activity in samples a and $\mathrm{b}$ of animals on the high-tannin ration (group 3) was lower than in the groups fed on the control ration (group 1) or the diet with low-tannin faba bean hulls (group 2; Table 4). No differences in aminopeptidase activity were found between three groups in sample c.

The differences in aminopeptidase activity between group 3 (high-tannin) and groups 1 (control) and 2 (low-tannin) were significant for sample a and for the mean values of samples a and b $(P<0.05)$.

Correlation between apparent faecal digestibility of protein and aminopeptidase activity. The aminopeptidase activity (Fig. 1) was depressed in the mucosa of animals fed on the ration with the high-tannin faba-bean hulls (group 3). From the previously described nutritional evaluation (Jansman et al. 1984), with the same rations, it was clear that a high tannin content in the ration decreases protein digestibility. Combining both observations the correlation between protein digestibility and aminopeptidase activity was calculated for the animals of group 3.

Fig. 1 shows the relationship between faecal protein digestibility ( $y$ axis) and mean aminopeptidase activity of the samples $\mathrm{a}, \mathrm{b}$ and $\mathrm{c}$ ( $x$ axis). A significant positive correlation 


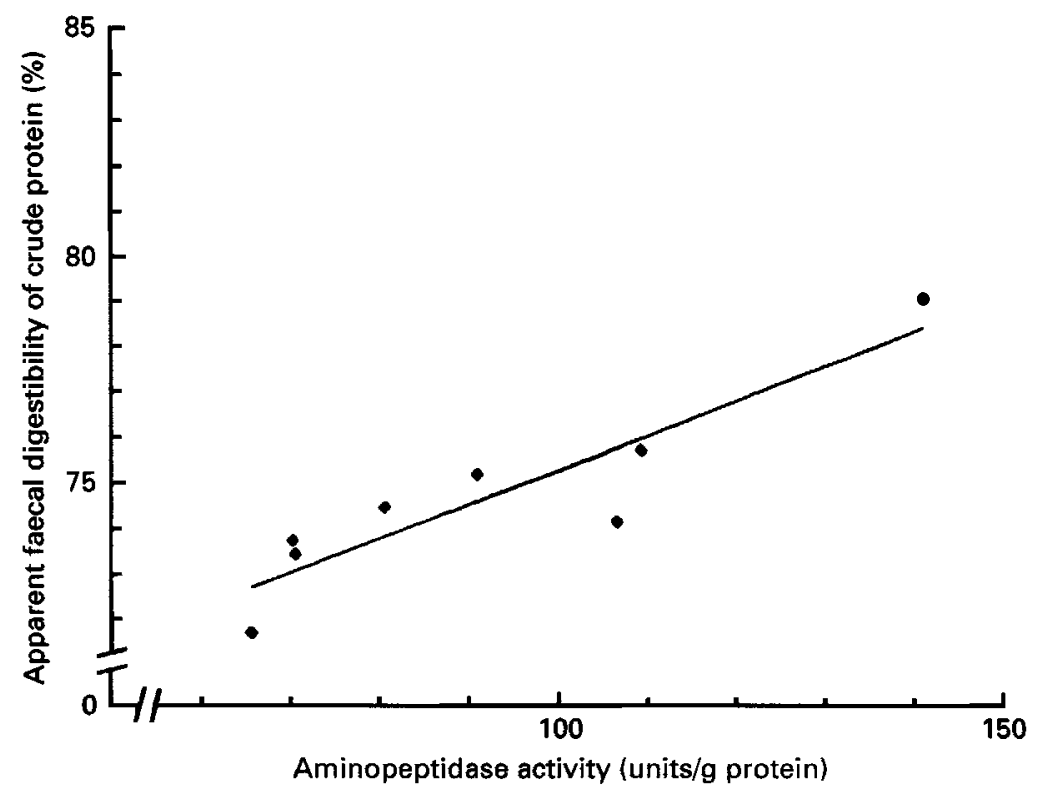

Fig. 1. Correlation between aminopeptidase ( $E C$ 3.4.11.2) activity and protein (crude protein; nitrogen $\times 6.25)$ digestibility for pigs fed on the high-tannin ration (treatment group 3). $y=0.075 x+67.8 ; r 0.91, P<0.002$. For details of rations and procedures, see pp. 32-33. One unit of amino peptidase activity is equal to the production of $1 \mu \mathrm{mol} p$-nitroaniline/min from the L-alanine-p-nitroanilide substrate.

was found between protein digestibility and aminopeptidase activity in the mucosa $(r 0.91$; $P<0.002 ; y=0.0745 x+67.8$ ). For groups 1 and 2 , no significant correlations were found.

\section{DISCUSSION}

One of the properties of condensed tannins is their affinity for proteins. Tannins in the intestinal tract bind proteins from feed as well as endogenous proteins. The hypothesis underlying the study was that, due to binding of tannins with proteins of the glycocalyx, the biochemical and physical properties of this layer change and induce morphological and/or functional changes of the small-intestinal mucosa.

Samples of the intestinal tissue were derived from a nutritional experiment with weaned pigs (Jansman et al. 1993). The results of that study showed that protein digestion decreased due to dietary tannins from faba beans. The increase in faecal $\mathrm{N}$ losses was partly explained by the increase in excretion of poorly digested tannin-feed protein complexes. Also the excretion of endogenous $\mathrm{N}$ was increased (Jansman et al. 1993). The results of the present study showed that morphological characteristics of the three groups of animals were similar and that dietary tannins did not induce significant changes. This means that tannins did not induce morphological changes in the small-intestinal mucosa. However, morphological variables of the small-intestinal mucosa of the control piglets showed rather large differences between animals. These differences may be related to differences in the local morphological structure of the mucosa, the conventional environment and/or genetic variation among the animals.

The biochemical activity in homogenates of mucosa and submucosa was characterized by rather large standard errors of means. In man, distinct differences in intestinal brushborder enzyme activity due to genetic variation have been observed (Junqueira \& Carneiro, 
1983). Sucrase-isomaltase activities in the three experimental groups were similar. However, aminopeptidase activity in homogenates of the proximal jejunum was depressed in the high-tannin group (3) compared with the control (1) and the low-tannin groups (2).

The effect of the tannins could be explained by a binding of dietary tannins with the protein site of the aminopeptidase-active enzymes. The difference in effect of tannins on sucrase-isomaltase and aminopeptidase activities is probably due to a difference in physical properties of the two enzymes. Sucrase has an extremely hydrophobic amino acid sequence at the N-terminal end (Brunner et al. 1979). Aminopeptidase (and maltase) has a hydrophilic 'head' that emerges entirely from the external microvillus membrane and two short domains inserted in the membrane and penetrating into the cytoplasm respectively (Maroux et al. 1979; Svenssen, 1979). Low activities of aminopeptidase and sucraseisomaltase were found in piglets fed on Phaseolus vulgaris beans (Kik et al. 1990). The decrease in the functional capacity of the mucosa in this case was associated with morphological abnormalities.

In the present study the enzyme activity analyses were performed in homogenates of the mucosa and submucosa. This means that the total activities of the brush-border and cytoplasmic enzymes were measured. Aminopeptidase is essential both for hydrolysis of small peptides and for active transport of amino acids in the brush-border membrane of the enterocytes. To study this aspect the correlation between protein digestibility and aminopeptidase activity was analysed. Results showed a significant $(P<0.002)$ positive correlation for the data from the group with the high-tannin ration (treatment group 3, Fig. 1). This observation indicates that aminopeptidase activity was a limiting factor for the rate of digestion of the protein in the ration with a high level of tannins.

\section{REFERENCES}

Bate-Smith, E. C. \& Swain, T. (1962). Flavonoid compounds. In Comparative Biachemistry, vol. 3, pp. 755-809 [M. Florkin and H. S. Mason, editors]. New York: Academic Press.

Bos, K. D. \& Jetten, J. (1989). Determination of tannins in faba beans. In Recent Advances of Research in Antinutritional Factors in Legume Seeds, pp. 285-296 [J. Huisman, A. F. B. van der Poel and I. E. Liener, editors]. Wageningen, The Netherlands: Pudoc.

Brunner, J. H., Hauser, H., Braun, H., Wilson, K. J., Wacker, H., O'Neil, B. \& Semenza, G. (1979). The mode of association of the enzyme complex sucrase-isomaltase with the intestinal brush-border membrane. Journal of Biological Chemistry 254, 1821-1828.

Egberts, H. J. A., Koninkx, J. F. J. G., van Dijk, J. E. \& Mouwen, J. M. V. M. (1984). Biological and pathobiological aspects of the glycocalyx of the small intestinal epithelium. Veterinary Quarterly 6, 186-199.

Jansman, A. J. M. (1993). Tannins in faba beans (Vicia faba L.) - antinutritional properties in monogastric animals. PhD Thesis, Agricultural University, Wageningen, The Netherlands.

Jansman, A. J. M., Verstegen, M. W. A. \& Huisman, J. (1993). Effects of inclusion hulls of faba beans ( $\mathrm{Vicia}$ faba L.) with low and high content of condensed tannins on digestibility and some physiological parameters in piglets. Animal Feed Science and Technology 43, 239-257.

Junqueira, L. C. \& Carneiro, J. (1983). Basic Histology, 4th ed. Los Altos, CA: Lange Medical Publications.

Kik, M. J. L., Huisman, J., van der Poel, A. F. B. \& Mouwen, J. M. V. M. (1990). Pathologic changes of the small intestinal mucosa of pigs after feeding Phaseolus vulgaris beans. Veterinary Pathology 27, 329-334.

Lowry, O. H., Rosebrough, N. J., Farr, A. L. \& Randall, R. J. (1951). Protein measurement with the Folin phenol reagent. Journal of Biological Chemistry 193, 265-275.

Maroux, S., Louvard, D. \& Baratti, J. (1973). The aminopeptidase from hog intestinal brush border. Biochimica et Biophysica Acta 321, 282-295.

Maroux, S., Louvard, D., Semeriva, M. \& Desnuelle, P. (1979). Hydrolyses bound to the brush border: an example of transmembrane proteins. Annales de Biologie Animale, Biochimie, Biophysique 19, 787.

Marquardt, R. R., Ward, A. T., Campbell, L. D. \& Cansfield, P. E. (1977). Purification, identification and characterization of a growth inhibitor in faba beans (Vicia faba L. var. minor). Journal of Nutrition 107, 1313-1324.

Martin-Tanguy, J., Guillaume, J. \& Kossa A. (1977). Condensed tannins in horse bean seeds: chemical structure and apparent effects on poultry. Journal of the Science of Food and Agriculture 28, 757-765.

Messer, M. \& Dahlqvist, A. (1966). A one step ultramicromethod for the assay of intestinal disaccharidases. Analytical Biochemistry 14, 376-392. 
Mitjavila, S., Lacombe, C., Carrera, G. \& Derache, R. (1977). Tannic acid and oxidized tannic acid on the functional state of rat intestinal epithelium. Journal of Nutrition 107, 2113-2121.

Mouwen, J. M. V. M. (1972). White scours in piglets at three weeks of age. PhD Thesis, University of Utrecht, The Netherlands.

Mouwen, J. M. V. M., Egberts, H. J. A. \& Koninkx, J. F. J. G. (1983). The outermost mucosal barrier of the mammalian small intestine. Deutsche Tierärztliche Wochenschrift 90, 477-482.

Salunkhe, D. K., Chavan, J. K. \& Kadam, S. S. (1990). Nutritional consequences of dietary tannins. In Dietary Tannins: Consequences and Remedies, pp. 113-146 [D. K. Salunkhe, J. K. Chavan and S. S. Kadam, editors]. Boca Raton, FL: CRC Press.

Snedecor, G. W. \& Cochran, W. G. (1980). Statistical Methods, 7th ed. Ames, Iowa: The Iowa State University Press.

Statistical Packages for Social Sciences (1992). System User's Guide. SPSS/PC $C^{+}$Version 5.0 Base. Chicago, Il: Marija J. Norusis/SPSS Inc.

Svenssen, B. (1979). Covalent cross-linking of porcine small-intestine microvillar aminopeptidase. Subunit structure of the membrane-bound and the solubilized enzyme. Carlsberg Research Communications 44, 417-427. 